\title{
Procedures for evaluating the tolerance of cassava genotypes to postharvest physiological deterioration
}

\author{
Marcela Tonini Venturini ${ }^{(1)}$, Vanderlei da Silva Santos ${ }^{(2)}$ and Eder Jorge de Oliveira(2) \\ (1)Universidade Federal do Recôncavo da Bahia, Campus Cruz das Almas, CEP 44380-000 Cruz das Almas, BA, Brazil. E-mail: \\ cosalin2@yahoo.com.br (2)Embrapa Mandioca e Fruticultura, Rua Embrapa, s/no-, Caixa Postal 007, CEP 44380-000 Cruz das Almas, BA, \\ Brazil. E-mail: eder.oliveira@embrapa.br, vanderlei.silva-santos@embrapa.br
}

\begin{abstract}
The objective of this work was to define procedures to assess the tolerance of cassava genotypes to postharvest physiological deterioration (PPD) and to microbial deterioration (MD). Roots of six cassava genotypes were evaluated in two experiments, during storage under different environmental conditions: high temperature and low soil moisture; or low temperature and high soil moisture. Roots were treated or not with fungicide (carbendazim) before storage. Genotype reactions to MD and PPD were evaluated at 0, 2, 5, 10, 15, 20 , and 30 days after harvest (DAH), in the proximal, medial, and distal parts of the roots. A diagrammatic scale was proposed to evaluate nonperipheral symptoms of PPD. Fungicide treatment and root position did not influence PPD expression; however, all factors had significant effect on MD severity. Genotypes differed as to their tolerance to PPD and MD. Both deterioration types were more pronounced during periods of higher humidity and lower temperatures. The fungicide treatment increased root shelf life by reducing MD severity up to $10 \mathrm{DAH}$. Whole roots showed low MD severity and high PPD expression up to $10 \mathrm{DAH}$, which enabled the assessment of PPD without significant interference of MD symptoms during this period.

Index terms: Manihot esculenta, genotype screening, microbial deterioration, procedure standardization, shelf life, storage conditions.

\section{Procedimentos para avaliar a tolerância de genótipos de mandioca à deterioração fisiológica pós-colheita}

Resumo - O objetivo deste trabalho foi definir procedimentos para a avaliação da tolerância de genótipos de mandioca à deterioração fisiológica pós-colheita (DFPC) e à deterioração microbiana (DM). Raízes de seis genótipos de mandioca foram avaliadas em dois experimentos, durante armazenamento em diferentes condições ambientais: alta temperatura e baixa umidade do solo; ou baixa temperatura e alta umidade do solo. As raízes foram tratadas ou não com fungicida (carbendazim) antes do armazenamento. As reações dos genótipos à DM e à DFPC foram avaliadas aos $0,2,5,10,15,20$ e 30 dias após a colheita (DAC), nas partes proximal, medial e distal das raízes. Uma escala diagramática foi proposta para avaliar sintomas não periféricos da DFPC. O tratamento com fungicida e a posição das raízes não influenciaram a expressão da DFPC; no entanto, todos os fatores apresentaram efeito significativo sobre a severidade da DM. Os genótipos diferiram quanto à tolerância à DFPC e à DM. Ambos os tipos de deterioração foram mais pronunciados durante os períodos de maior umidade e de temperaturas mais baixas. $\mathrm{O}$ tratamento com fungicida proporcionou maior vida de prateleira às raízes, por reduzir a severidade da DM até $10 \mathrm{DAC}$. As raízes inteiras apresentaram baixa severidade da DM e alta expressão da DFPC até 10 DAC, o que possibilitou a avaliação da DFPC sem interferência significativa dos sintomas da DM nesse período.

Termos para indexação: Manihot esculenta, triagem de genótipos, deterioração microbiana, padronização de procedimentos, vida de prateleira, condições de armazenamento.

\section{Introduction}

Cassava (Manihot esculenta Crantz) is considered a rustic crop, with some tolerance to drought, low soil fertility, and to some diseases and pests; however, its roots have a short shelf life after harvest, due to a process known as postharvest physiological deterioration (PPD) (Salcedo \& Siritunga, 2011).

Considered a complex enzymatic process, PPD (Owiti et al., 2011) begins $15 \mathrm{~min}$ after the root cutting, and becomes visible between 24 and 72 hours after harvest, rendering roots inappropriate for consumption 
(Sánchez et al., 2006; Reilly et al., 2007; Morante et al., 2010). The main symptoms of PPD include vascular streaking, which is a blue-black discoloration of the xylem parenchyma, followed by general discoloration of the parenchyma, forming vascular ridges (Reilly et al., 2003).

The development of PPD and its severity in cassava have been strongly associated to environmental factors and mechanical damage, mainly during harvest, transport, and storage of roots (Salcedo \& Siritunga, 2011). The physiological process can be subdivided into two distinct phases. In the first one, there is a rapid cyanide-induced production of reactive oxygen species (ROS), which initiates a programmed cell death. In the second, which usually begins at the $5^{\text {th }}$ day after harvest, the onset of microbial deterioration (MD) occurs, resulting in severe root rot (Reilly et al., 2003).

To extend the shelf life of roots, some control measures of PPD and MD have been suggested, such as wrapping roots with vacuum packaging (Luengo \& Galbo, 2009) in polyethylene bags, coating them with paraffin, and storing them at low temperatures (Huang et al., 2001; Morante et al., 2010). However, these techniques have been rarely used in the cassava production system because of their high cost, or due to the lack of consistent beneficial results. In contrast, the selection of tolerant genotypes to PPD constitutes an alternative to ensure higher cassava competitiveness by increasing its root shelf life after harvest.

As there is a genetic component associated to PPD tolerance (Morante et al., 2010; Salcedo et al., 2010), the wide genetic variability in Brazilian cassava germplasm can be used to overcome losses. However, the large number of factors affecting the expression of PPD symptoms limits the effectiveness of genotype selection. Although information on genotype tolerance to PPD has not been systematized yet, the measurements which should be carried out, the growing conditions, and the sample size are of the utmost importance to assess PPD and to obtain stable, tolerant genotypes (Zidenga et al., 2012).

One of the methodologies to evaluate visual PPD is the use of a diagrammatic scale of symptoms ranging from 0 to $100 \%$ (Wheatley et al., 1985). However, this scale is restricted for assessing the perimeter area of the roots, and several cassava accessions do not fit it, due to the absence of peripheral PPD symptoms. Moreover, there is a lack in methodology standardization for selecting tolerant genotypes regarding the number of roots, evaluation period, and the parts of the root to be evaluated (Wheatley et al., 1985; Ekanayake \& Lyasse, 2003; Morante et al., 2010; Salcedo et al., 2010).

The objective of this work was to define procedures to assess the tolerance of cassava genotypes to postharvest physiological deterioration (PPD) and to microbial deterioration (MD).

\section{Materials and Methods}

The experiments were carried out at the experimental fields of Embrapa Mandioca e Fruticultura, Cruz das Almas, BA, Brazil (1240'19"S, 3906'22"W, at 226-m altitude). The region has Aw and Am tropical climate, with $24.5^{\circ} \mathrm{C}$ annual mean temperature, $80 \%$ relative humidity, and 1,250-mm precipitation.

The assessment of PPD expression and MD severity was made in the roots of the following cassava genotypes: BRS Caipira, BRS Dourada, BRS Mulatinha, BRS Poti Branca, BGM1685, and BGM0212.

Root harvest was performed manually 12 months after planting; special care was taken to avoid injuries to the roots, and only commercial-quality ones were selected. Two experiments were carried out in different environmental conditions. The first experiment was performed in January 2014 under conditions of high temperature and low soil moisture content (high temperature + low humidity, HTLH), with the roots being kept indoors at an average temperature of $27 \pm 1^{\circ} \mathrm{C}$. No pluvial precipitation was recorded during this period, and the average relative humidity was $76 \pm 3 \%$. The second experiment was done in March 2014 , under conditions of low temperature and moist soil (low temperature + high humidity, LTHH), with the roots being kept indoors at an average temperature of $22 \pm 1^{\circ} \mathrm{C}$. During this period, $6.1-\mathrm{mm}$ precipitation was recorded and the average relative humidity was $87 \pm 3 \%$. In the first experiment, the harvest occurred in dry soil at high temperature; and in the second one, the harvest occurred in moist soil at medium temperature.

After harvest, the soil excess was wiped up from the roots, and the disinfection was done by soaking them in sodium hypochlorite solution $\left(200 \mathrm{mg} \mathrm{L}^{-1}\right)$ for $5 \mathrm{~min}$. Then, half of the roots was immersed for $2 \mathrm{~min}$ in a fungicide suspension with $50 \mu \mathrm{g} \mathrm{mL}^{-1}$ methyl benzimidazole-2-yl-carbamate (carbendazim). 
The roots were stored on shelves, in a covered, open shed with free air circulation. Visual assessments of PPD symptoms were performed in five roots at $0,2,5$, $10,15,20$, and 30 days after harvest (DAH). Transverse sections of $1.0 \mathrm{~cm}$ were made in the proximal, medial, and distal positions of the roots, at 25,50 , and $75 \%$ of the length from the base, respectively.

The severity levels of PPD were evaluated using a diagrammatic scale, from 0 to $100 \%$, of the peripheral distribution of symptoms (Wheatley et al., 1985). Moreover, a nonperipheral diagrammatic scale was proposed for evaluating nonperipheral distribution of symptoms (Figure 1).

The analysis of MD was based on a descriptive scale with the following assignment of scores: 0 , for no rotten roots; 1 , for roots showing firmness loss;
2, for softening roots; and 3, for roots without any firmness, with an aqueous aspect. These evaluations were performed on the same dates and root positions used for the PPD evaluation.

The descriptive scale for MD was transformed into an infection intensity index, expressed as $\quad \mathrm{I}=\operatorname{sen}^{2} \omega$, whose angular transformation ( $\omega=\operatorname{arcsen} \sqrt{\mathrm{I}})$ allows for the application of variance analysis (Czermainski, 1999); $\omega$ is given by

$$
\omega=\sum_{\mathrm{j}=1}^{\mathrm{J}} \mathrm{k}_{\mathrm{j}} \sqrt{\mathrm{p}_{\mathrm{j}=1, \mathrm{~J}}} \operatorname{arcsen} \sqrt{\mathrm{f}_{\mathrm{j}}}
$$

in which: $\mathrm{k}_{\mathrm{j}}$ are weighing constants determined from the assignment of the maximum theoretical I value, corresponding to each note of the scale, given by
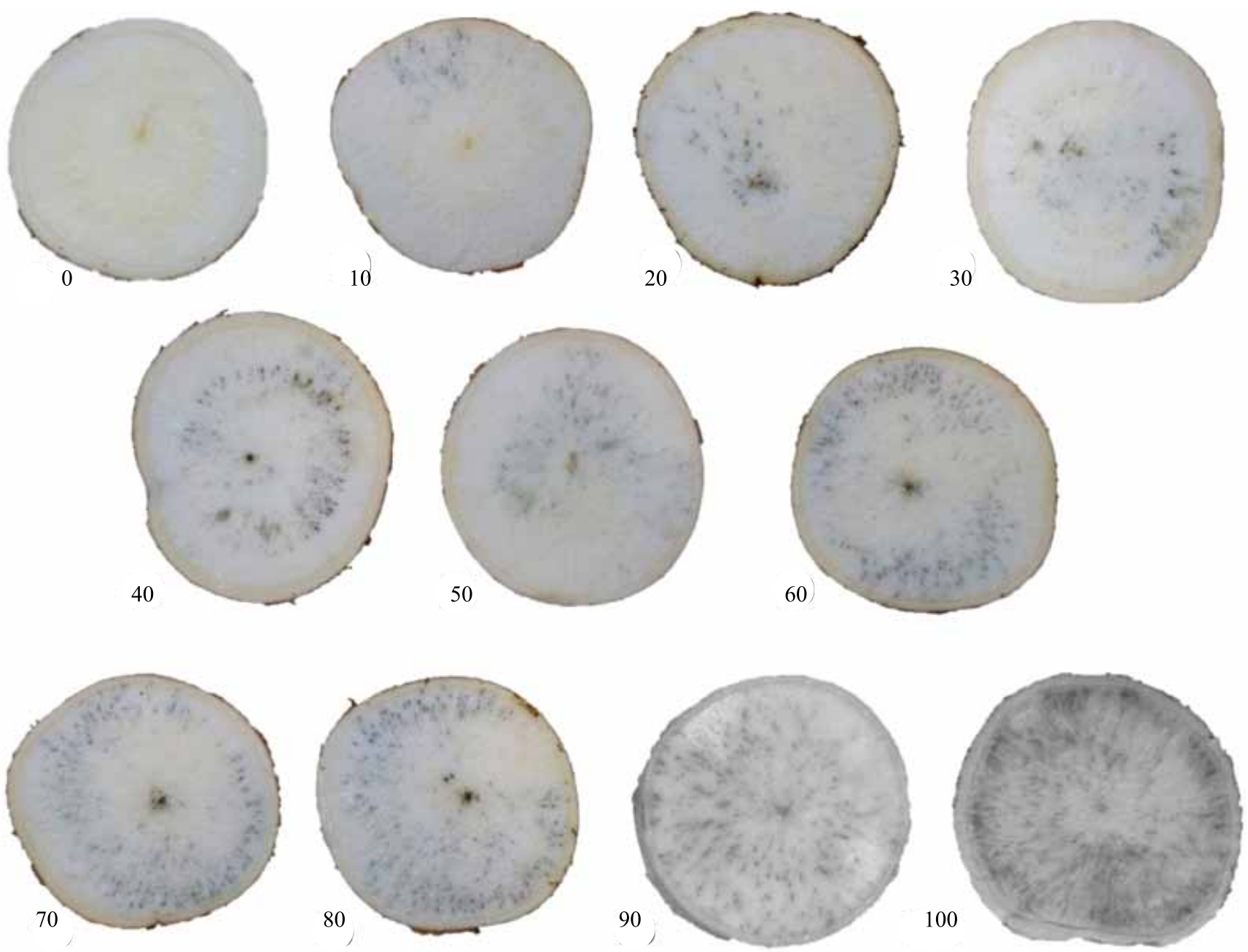

Figure 1. Proposed diagrammatic scale of postharvest physiological deterioration based on the distribution of nonperipheral symptoms in cassava roots. 


$$
\mathrm{k}_{\mathrm{j}}=\left(\operatorname{arcsen} \sqrt{\mathrm{j}^{\prime} / \mathrm{J}}\right) / 90-\mathrm{k}_{1}-\mathrm{k}_{2}-\ldots-\mathrm{k}_{\mathrm{j}-1}=1-\sum_{\mathrm{j}=1}^{\mathrm{J}-1} \mathrm{k}_{\mathrm{j}}
$$

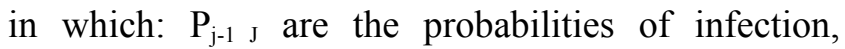
associated to each disease scale for the individual whose infection intensity index is being determined, expressed by $P_{j-1} J=p_{j}+p_{j+1}+\ldots+p_{j}, j=1, \ldots J$; and $f_{j}$ are relative frequencies representing fractions of the absolute frequency $\left(F_{j}\right)$ given by $f_{j}=(F j+F j+1+\ldots+$ $\left.F_{j}\right) /\left(F_{j-1}+F_{j}+F_{j+1}+F_{j}+\ldots+f_{j}\right), j=1, \ldots, J$.

For each environmental condition (HTLH and LTHH), a randomized complete block design was carried out, in a factorial arrangement of six genotypes (BRS Caipira, BRS Dourada, BRS Mulatinha, BRS Poti Branca, BGM1685, and BGM0212), with or without fungicide treatment and seven evaluation times $(0,2,5,10,15,20$, and 30 days $)$, with three replicates and five roots per plot.

Data were subjected to analysis of variance, and the means were compared by Tukey's test at 5\% probability. For both cases, R software, version 3.01 (R Foundation for Statistical Computing, Vienna, Austria) was used.

\section{Results and Discussion}

The PPD was significantly influenced by environmental conditions (EC), genotypes (G), and days after harvest (DAH), with the following significant interactions: $\mathrm{G} \times \mathrm{EC} ; \mathrm{G} \times \mathrm{FT}$ (fungicide treatment); G $\times$ DAH; G $\times$ RoPo (root position); $\mathrm{DAH}$ $\mathrm{x}$ EC, and DAH x FT (Table 1). Tolerance degree to PPD increased according to the following sequence of genotypes: BRS Caipira, BRS Mulatinha, BRS Poti

Table 1. Summary of the analysis of variance for the evaluation of postharvest physiological deterioration (PPD) and microbial deterioration (MD) in six cassava genotypes.

\begin{tabular}{|c|c|c|}
\hline Source of variation & PPD & MD \\
\hline Genotype (G) & $355,365.00^{* * *}$ & $2,528.00 * * *$ \\
\hline Environmental conditions (EC) & $18,689.00 * * *$ & $3,376.00 * * *$ \\
\hline Fungicide treatment (FT) & $28.00^{\text {ns }}$ & $103,916.00^{* * *}$ \\
\hline Days after harvest (DAH) & $375,695.00^{* * *}$ & $84,070.00 * * *$ \\
\hline Blocks & $3,374.00^{*}$ & $588.00 *$ \\
\hline Root position (RoPo) & $208.00^{\mathrm{ns}}$ & $861.00 * *$ \\
\hline $\mathrm{G} \times \mathrm{EC}$ & $12,340.00 * * *$ & $943.00 * * *$ \\
\hline $\mathrm{G} \times \mathrm{FT}$ & $5,475.00 * * *$ & $1,299.00 * * *$ \\
\hline $\mathrm{G} \times \mathrm{DAH}$ & $18,525.00 * * *$ & $703.00 * * *$ \\
\hline $\mathrm{G} \times \mathrm{RoPo}$ & $3,905.00 * * *$ & $205.00^{\mathrm{ns}}$ \\
\hline $\mathrm{EC} \times \mathrm{FT}$ & $1,725.00^{\mathrm{ns}}$ & $8,112.00 * * *$ \\
\hline $\mathrm{EC} \times \mathrm{DAH}$ & $2,694.00 * *$ & $1,854.00 * * *$ \\
\hline $\mathrm{EC} \times \mathrm{RoPo}$ & $1,420.00^{\mathrm{ns}}$ & $627.00^{*}$ \\
\hline $\mathrm{FT} \times \mathrm{DAH}$ & $2,304.00$ & $18,834.00 * * *$ \\
\hline $\mathrm{FT} \times \mathrm{RoPo}$ & $642.00^{\mathrm{ns}}$ & $158.00^{\mathrm{ns}}$ \\
\hline $\mathrm{DAH} \times \mathrm{RoPo}$ & $756.00^{\mathrm{ns}}$ & $296.00^{\mathrm{ns}}$ \\
\hline
\end{tabular}

$*$, ** and ***Significant by the $\mathrm{F}$ test at 5,1 , and $0.1 \%$ probability, respectively.

Table 2. Interaction effect between genotypes and environmental conditions (EC), fungicide treatment, period after harvest, and root position, on the severity of postharvest physiological deterioration (from 0 to $100 \%$ ) in cassava roots, according to diagrammatic scales of the peripheral distribution of symptoms (Wheatley et al., 1985) and to the proposed scale of nonperipheral symptoms ${ }^{(1)}$.

\begin{tabular}{|c|c|c|c|c|c|c|c|c|c|c|c|c|c|c|c|}
\hline \multirow[t]{2}{*}{ Genotype } & \multicolumn{2}{|c|}{$\mathrm{EC}$} & \multicolumn{2}{|c|}{ Fungicide } & \multicolumn{7}{|c|}{ Period after harvest (days) } & \multicolumn{3}{|c|}{ Root position } & \multirow[t]{2}{*}{$\overline{\text { Average }}$} \\
\hline & HTLH & LTHH & Untreated & Treated & 0 & 2 & 5 & 10 & 15 & 20 & 30 & Proximal & Medial & Distal & \\
\hline BRS Caipira & $56.0 \mathrm{bA}$ & $66.5 \mathrm{aA}$ & $57.4 \mathrm{bA}$ & $63.8 \mathrm{aA}$ & $0.0 \mathrm{cA}$ & $74.6 \mathrm{bA}$ & $86.5 \mathrm{aA}$ & $84.0 \mathrm{abA}$ & $78.8 \mathrm{abA}$ & $72.4 \mathrm{bA}$ & $32.5 \mathrm{bcAB}$ & $54.7 \mathrm{bA}$ & $64.2 \mathrm{aA}$ & $65.0 \mathrm{aA}$ & 61.2 \\
\hline BRS Mulatinha & $51.9 \mathrm{bA}$ & $59.8 \mathrm{aB}$ & $51.1 \mathrm{bB}$ & $59.3 \mathrm{aA}$ & $0.0 \mathrm{cA}$ & $61.9 \mathrm{bB}$ & $80.1 \mathrm{aAB}$ & $76.3 \mathrm{aAB}$ & 72.6abA & 73.9abA & $17.5 \mathrm{bcAB}$ & $53.7 \mathrm{aA}$ & $56.4 \mathrm{aB}$ & $57.9 \mathrm{aB}$ & 55.2 \\
\hline BRS P Branca & $50.8 \mathrm{aA}$ & $53.2 \mathrm{aC}$ & $51.9 \mathrm{aAB}$ & $52.1 \mathrm{aB}$ & $0.0 \mathrm{cA}$ & $66.4 \mathrm{bAB}$ & $77.8 \mathrm{aB}$ & $69.5 \mathrm{abB}$ & 67.9abA & $54.5 \mathrm{bB}$ & 73.1abA & $55.7 \mathrm{aA}$ & $50.7 \mathrm{abB}$ & $49.6 \mathrm{bC}$ & 55.2 \\
\hline BGM1685 & $28.8 \mathrm{bB}$ & $36.2 \mathrm{aD}$ & $36.0 \mathrm{aC}$ & $30.0 \mathrm{bC}$ & $0.0 \mathrm{bA}$ & $39.7 \mathrm{aC}$ & $41.4 \mathrm{aC}$ & $41.2 \mathrm{aC}$ & $42.9 \mathrm{aB}$ & $41.9 \mathrm{aB}$ & - & $36.6 \mathrm{aB}$ & 33.0abC & $28.9 \mathrm{bD}$ & 33.6 \\
\hline BRS Dourada & $22.2 \mathrm{bC}$ & $29.7 \mathrm{aE}$ & $28.8 \mathrm{aD}$ & $24.0 \mathrm{bD}$ & $0.0 \mathrm{cA}$ & $30.5 \mathrm{abD}$ & $39.0 \mathrm{aC}$ & $33.4 \mathrm{abC}$ & $36.3 \mathrm{abB}$ & $25.8 \mathrm{bC}$ & $10.5 \mathrm{bcB}$ & $26.2 \mathrm{aC}$ & $27.1 \mathrm{aC}$ & $24.5 \mathrm{aD}$ & 25.6 \\
\hline BGM0212 & $14.0 \mathrm{aD}$ & $04.7 \mathrm{bF}$ & $10.4 \mathrm{aE}$ & $07.8 \mathrm{aE}$ & $0.0 \mathrm{cA}$ & $07.0 \mathrm{bcE}$ & 15.3abD & $07.7 \mathrm{bcD}$ & $19.8 \mathrm{aC}$ & $08.1 \mathrm{bcD}$ & $03.8 \mathrm{bcB}$ & $10.1 \mathrm{aD}$ & $08.9 \mathrm{aD}$ & $07.8 \mathrm{aE}$ & 9.0 \\
\hline Average & 37.3 & 41.7 & 39.3 & 39.5 & 0.0 & 46.7 & 56.7 & 52.0 & 53.1 & 46.1 & 27.5 & 39.5 & 40.1 & 39.0 & 39.9 \\
\hline
\end{tabular}

(1)Means followed by equal lowercase letters, in the rows, and capital letters, in the columns, do not differ by Tukeys test, at 5\% probability. HTLH, trial carried out under conditions of high temperature and low soil moisture; and LTHH, trial carried out under conditions of low temperature and high soil moisture. Treated, immersion of the roots in fungicide ( $50 \mu \mathrm{g} \mathrm{mL}^{-1}$ carbendazim) solution for $2 \mathrm{~min}$; untreated, roots not immersed in fungicide solution. 
Branca, BGM1685, BRS Dourada, and BGM0212 (Table 2). The genotypes BRS Dourada and BGM0212, with high tolerance to PPD, had creamy and yellow pulp respectively. This result agrees with that of Sánchez et al. (2006), who reported a higher tolerance to PPD in genotypes with high carotenoid contents. On the whole, these results show that not only is PPD dependent on the environmental conditions, but also on the genetic background, which is an information of utmost importance for breeding programs, and for cassava growers.

The PPD symptoms were more pronounced in LTHH conditions, except for 'BGM0212'. Therefore, the differentiation between is more visible when the roots are harvested after the first rains (LTHH conditions), which also promoted a greater ease for harvesting the roots. The genotypes BGM0212, BRS Dourada, and BGM1685 had the lowest PPD expression, irrespective of the environmental condition (Table 2).

According to Wheatley et al. (1985), some environmental factors, such as temperature and relative humidity, influence the expression of PPD, mainly in the presence of mechanical damage. This is a major constraint for cassava crop, since wounding and mechanical damaging cannot be prevented during harvesting (Huang et al., 2001). The higher expression of PPD under LTHH conditions do not agree with other studies, in which the expression of symptoms were lower in roots harvested with moist soil, in comparison to those harvested with low soil moisture (Ekanayake \& Lyasse, 2003). According to Huang et al. (2001), the typical PPD symptoms occur faster when the crop is harvested under low humidity storage.

The lack of significance of the fungicide treatment on PPD expression indicates that this treatment can be used in the screening of genotypes, since it delays the onset of MD but does not affect PPD. The $\mathrm{G} \times \mathrm{FT}$ interaction, however, showed that there was no consensus in the PPD manifestation in treated and untreated genotypes, considering the greatest expression of PPD in 'BRS Dourada' and 'BGM1685' without fungicide treatment, and in 'BRS Caipira' and 'BRS Mulatinha' when the treatment was used (Table 2). Notwithstanding these differences, the behavior of 'BGM0212' and 'BRS Poti Branca' did not vary irrespectively of the fungicide treatment. These results indicate a strong genetic component in the expression of PPD symptoms. According to Alves et al. (2008), vascular darkness occurs more quickly on cylinders of untreated, peeled roots compared to roots treated with a fungistatic solution, composed of sodium hypochlorite and citric acid.

Considering $\mathrm{G} \times \mathrm{DAH}$ interaction, PPD symptoms began two days after harvest, peaking at $5 \mathrm{DAH}$ (Table 2). For most of the genotypes, PPD values decreased after this point. This result is counter-intuitive, as PPD tends to increase over time. However, a hypothesis to explain this discrepancy is that from $5 \mathrm{DAH}$ on several roots were lost by $\mathrm{MD}$; therefore, only roots with little mechanical damage during harvesting remained in the analysis and, thereby, contributed to a lower expression of PPD, independently of the evaluated genotype. At 10, 15, and $20 \mathrm{DAH}$, PPD values were quite variable. This fluctuation in the symptoms was also observed by Morante et al. (2010), who observed higher PPD values at $10 \mathrm{DAH}$ than at 20 and $40 \mathrm{DAH}$. Differences in the expression of PPD symptoms may be due to variation in environmental conditions and in genotype tolerance. In general, the BGM0212, BRS Dourada, and BGM1685 genotypes showed the lowest values of PPD, regardless of the evaluation time.

Concerning the $\mathrm{G} \times$ RoPo interaction, the PPD values in the proximal, medial, and distal root positions were $39.5,40.1$, and $39.0 \%$, respectively, which is very close and indicates that anyone of these positions can be used for evaluating PPD. However, the medial position should provide a greater stability in the evaluation, as injuries and traumas are generally more pronounced at root ends. Consequently, the MD occurred earlier in these positions, making it difficult the maintenance of roots for future PPD evaluations. The average PPD values for 'BGM0212', 'BRS Dourada', and 'BGM1685' were $8.9,25.9$, and $32.8 \%$, respectively, regardless of the root position, which are below the overall average $(39.5 \%)$. According to Salcedo \& Siritunga (2011), root injuries during harvest occur mainly in the proximal and distal parts. Moreover, Iyer et al. (2010) reported that PPD moves from proximal to distal parts. However, our results do not corroborate those observations.

Regarding DAH $\times$ FT interaction, the differences in PPD values between the fungicide and control treatments up to $10 \mathrm{DAH}$ were relatively small. From that day on, the expression of PPD symptoms was higher in roots subjected to FT (Table 3). 
As to $\mathrm{EC} \times \mathrm{DAH}$ interaction, the PPD severity peaked at $5 \mathrm{DAH}$, irrespectively of weather conditions at harvest (Table 3). From 10 DAH on, PPD values between HTLH and LTHH differed at 10 and $20 \mathrm{DAH}$,

Table 3. Interaction effect between period after harvest and fungicide treatment, and environmental conditions, on the severity of postharvest physiological deterioration (from 0 to $100 \%$ ) in cassava roots, according to diagrammatic scales of the peripheral distribution of symptoms (Wheatley et al., 1985) and to the proposed scale of nonperipheral symptoms ${ }^{(1)}$.

\begin{tabular}{lccccc}
\hline $\begin{array}{l}\text { Days after } \\
\text { harvest }\end{array}$ & \multicolumn{2}{c}{ Fungicide treatment } & & \multicolumn{2}{c}{ Environmental condition } \\
\cline { 2 - 3 } \cline { 5 - 6 } & Untreated & Treated & & HTLH & LTHH \\
\hline 0 & $0.0 \mathrm{aC}$ & $0.0 \mathrm{aE}$ & & $0.0 \mathrm{aD}$ & $0.0 \mathrm{aD}$ \\
2 & $43.7 \mathrm{bB}$ & $49.7 \mathrm{aB}$ & & $46.6 \mathrm{aB}$ & $46.8 \mathrm{aC}$ \\
5 & $53.1 \mathrm{bA}$ & $60.2 \mathrm{aA}$ & & $55.0 \mathrm{aA}$ & $57.9 \mathrm{aA}$ \\
10 & $48.6 \mathrm{aAB}$ & $47.5 \mathrm{aB}$ & & $43.3 \mathrm{bBC}$ & $52.2 \mathrm{aB}$ \\
15 & $50.7 \mathrm{aA}$ & $38.5 \mathrm{bC}$ & & $46.1 \mathrm{aB}$ & $49.8 \mathrm{aBC}$ \\
20 & $43.7 \mathrm{aB}$ & $25.7 \mathrm{bCD}$ & & $37.1 \mathrm{bC}$ & $43.9 \mathrm{aC}$ \\
30 & $10.5 \mathrm{aC}$ & $2.2 \mathrm{aDE}$ & & $14.2 \mathrm{aD}$ & $6.0 \mathrm{aD}$ \\
\hline
\end{tabular}

${ }^{(1)}$ Means followed by equal lowercase letters, in the rows, and capital letters, in the columns, do not differ by Tukey's test, at $5 \%$ probability. HTLH, trial carried out under conditions of high temperature and low soil moisture; and LTHH, trial carried out under conditions of low temperature and high soil moisture. Treated, immersion of the roots in fungicide (50 $\mu \mathrm{g} \mathrm{mL}^{-1}$ carbendazim) solution for $2 \mathrm{~min}$; untreated, roots not immersed in fungicide solution. when there was a tendency for greater PPD in LTHH conditions, which occurred in periods of rain during harvest, and under storage at lower temperatures.

The MD was influenced by genotypes, environmental conditions, fungicide treatment, days after harvest, root position, and also by the interactions ( $\mathrm{G} \times \mathrm{EC}$; $\mathrm{G}$ x FT; G x DAH; EC x FT; EC x DAH; RoPo x EC; and FT $x$ DAH). The only interactions which were not significant were $\mathrm{G} \times \mathrm{RoPo}, \mathrm{FT} \times \mathrm{RoPo}$, and DAH x RoPo.

Microbial deterioration was remarkably severe on 'BRS Dourada', with overall infection intensity index average of 25.6, followed by 'BRS Mulatinha' (22.4), 'BRS Poti Branca' (21.7), 'BGM1685' (20.1), 'BRS Caipira' (19.1), and 'BGM0212' (15.9) (Table 4). Considering the $\mathrm{G} \times \mathrm{EC}$ interaction, a high MD was observed under LTHH conditions, with lower temperatures during both harvest and postharvest, mainly for 'BRS Dourada' and 'BRS Mulatinha'. 'BGM1685', 'BRS Caipira', 'BRS Poti Branca', and 'BGM0212' did not show a significant difference in MD under different environmental conditions. The genotype BGM0212 had an MD value below the average, regardless of EC.

These results show that the MD appears to be more severe when roots are harvested under high humidity conditions. According to Salami \& Akintokun (2008), the most frequently pathogens which cause MD in cassava are Lasiodiplodia theobromae, Macrophomina

Table 4. Interaction effect between genotypes and environmental conditions, fungicide treatment, days after harvest, and root position, on microbial deterioration $^{(1)}$ in cassava roots $^{(2)}$.

\begin{tabular}{|c|c|c|c|c|c|c|c|c|c|c|c|c|}
\hline \multirow[t]{2}{*}{ Genotype } & \multicolumn{2}{|c|}{ Environmental condition } & \multicolumn{2}{|c|}{ Fungicide treatment } & \multicolumn{7}{|c|}{ Days after harvest } & \multirow[t]{2}{*}{ Average } \\
\hline & HTLH & LTHH & Untreated & Treated & 0 & 2 & 5 & 10 & 15 & 20 & 30 & \\
\hline BRS Dourada & $17.1 \mathrm{bA}$ & $30.1 \mathrm{aA}$ & $34.2 \mathrm{aA}$ & $14.3 \mathrm{bA}$ & $0.0 \mathrm{eA}$ & $0.0 \mathrm{eA}$ & $3.6 \mathrm{eA}$ & $21.9 \mathrm{dAB}$ & $39.9 \mathrm{bcA}$ & $51.3 \mathrm{bA}$ & $69.7 \mathrm{aAB}$ & 25.6 \\
\hline BRS Mulatinha & $14.6 \mathrm{bA}$ & $21.4 \mathrm{aB}$ & $31.0 \mathrm{aAB}$ & $4.4 \mathrm{bC}$ & $0.0 \mathrm{dA}$ & $0.0 \mathrm{dA}$ & $0.7 \mathrm{dA}$ & $20.4 \mathrm{cAB}$ & $34.3 \mathrm{bAB}$ & $42.3 \mathrm{bAB}$ & $77.1 \mathrm{aAB}$ & 22.4 \\
\hline BRS Poti Branca & $18.7 \mathrm{aA}$ & $18.8 \mathrm{aBC}$ & $28.7 \mathrm{aBC}$ & $10.8 \mathrm{bAB}$ & $0.0 \mathrm{cA}$ & $0.0 \mathrm{cA}$ & $4.5 \mathrm{cA}$ & $28.7 \mathrm{bA}$ & $36.8 \mathrm{abA}$ & $42.4 \mathrm{aB}$ & $49.7 \mathrm{aCD}$ & 21.7 \\
\hline BGM1685 & $16.9 \mathrm{aA}$ & $15.3 \mathrm{aC}$ & $22.8 \mathrm{aD}$ & $9.4 \mathrm{bABC}$ & $0.0 \mathrm{dA}$ & $0.0 \mathrm{dA}$ & $0.6 \mathrm{dA}$ & $13.7 \mathrm{cBC}$ & $29.0 \mathrm{bBC}$ & $36.1 \mathrm{bB}$ & $77.7 \mathrm{aA}$ & 20.1 \\
\hline BRS Caipira & $17.0 \mathrm{aA}$ & $13.8 \mathrm{aC}$ & $24.8 \mathrm{aCD}$ & $7.0 \mathrm{bBC}$ & $0.0 \mathrm{dA}$ & $0.0 \mathrm{dA}$ & $1.5 \mathrm{dA}$ & $19.3 \mathrm{cBC}$ & $33.8 \mathrm{bABC}$ & $34.2 \mathrm{bB}$ & $58.7 \mathrm{aBC}$ & 19.1 \\
\hline BGM0212 & $13.8 \mathrm{aA}$ & $16.5 \mathrm{aBC}$ & $20.8 \mathrm{aD}$ & $10.0 \mathrm{bAB}$ & $0.0 \mathrm{dA}$ & $0.0 \mathrm{dA}$ & $2.0 \mathrm{cdA}$ & $10.3 \mathrm{cC}$ & $24.9 \mathrm{bC}$ & $33.2 \mathrm{abB}$ & $43.1 \mathrm{aD}$ & 15.9 \\
\hline Average & 16.4 & 19.3 & 27.1 & 9.3 & 0.0 & 0.0 & 2.2 & 19.1 & 33.1 & 39.9 & 62.7 & 20.8 \\
\hline
\end{tabular}

(1)Transformed to infection intensity index (Czermainski, 1999). ${ }^{(2)}$ Means followed by equal lowercase letters, in the rows, and capital letters, in the columns, do not differ by Tukeys test, at 5\% probability. HTLH, trial carried out under conditions of high temperature and low soil moisture; and LTHH, trial carried out under conditions of low temperature and high soil moisture. Treated, immersion of roots in fungicide (50 $\mu \mathrm{g} \mathrm{mL} \mathrm{m}^{-1}$ carbendazim) solution for $2 \mathrm{~min}$; untreated, roots not immersed in fungicide solution. 
phaseolina, Rhizopus stolonifer, and Fusarium pallidoroseum. In general their growth is favored under high humidity.

As to $\mathrm{G} \times \mathrm{FT}$ interaction, roots without fungicide treatment had higher MD infection index for all genotypes (Table 4). The genotypes BGM1685 and BRS Caipira had MD below the average, regardless of FT, indicating that there may be a genetic effect involved on MD severity.

For $\mathrm{G} \times \mathrm{DAH}$ interaction, the MD had a progressive growth between 5 and $10 \mathrm{DAH}$, with a significant difference between genotypes in this period. The differences between genotypes begin to appear from $10 \mathrm{DAH}$, possibly due to reduction in the fungicide effect. The largest increase in MD was observed between 20 and 30 DAH. Huang et al. (2001) did not find visible signs of bacterial/fungal infection during 17 days of storage, at $30^{\circ} \mathrm{C}$ (relative humidity around $50 \%$ ). However, the cultivar analyzed by these authors (M Col 22) is highly sensitive to PPD, but fairly resistant to secondary deterioration. Additionally, their experiment was conducted under low relative humidity, which may explain the delay in the onset of MD symptoms.

In general, 'BGM0212' and 'BGM1685' had lower MD infection indexes throughout the evaluation period, but mainly until $20 \mathrm{DAH}$. At $30 \mathrm{DAH}$, the genotype BGM1685 showed similar behavior to that of the others. Therefore, the genetic component was an important factor to explain MD severity. Salami \& Akintokun (2008) reported severe MD in 'Odongbo' and 'TMS 4(2)1425', and moderate susceptibility in 'Oko-Iyawo'.

Regarding the DAH $\times$ FT interaction, the fungicide treatment delayed the MD onset to $10 \mathrm{DAH}$, while in the absence of FT symptoms began at 5 DAH (Table 5).
Significant differences between fungicide treatments were observed in daily evaluations throughout the study period.

For the EC $\times$ FT interaction, higher MD was observed in the untreated roots, with a tendency of increasing MD severity under LTHH conditions (Table 6). For EC $\times$ DAH interaction, a progressive increase in the MD was observed along the 30 days of evaluation, with the onset of symptoms after the 5 DAH. Higher MD was observed under HTLH until $10 \mathrm{DAH}$. After $15 \mathrm{DAH}, \mathrm{MD}$ values were higher under LTHH conditions. For the EC x RoPo interaction, the MD symptoms were higher under LTHH conditions, with significant difference between proximal and distal positions throughout the evaluation period (Table 6).

The recent report of genetic variation for tolerance to PPD (Morante et al., 2010) has entailed a new opportunity to explore such variation in cassava crop systems and breeding programs. The results of the present study contribute for the standardization

Table 5. Interaction effect between fungicide treatment and days after harvest, on microbial deterioration ${ }^{(1)}$ in cassava $\operatorname{roots}^{(2)}$.

\begin{tabular}{lccccccc}
\hline Fungicide & \multicolumn{7}{c}{ Days after harvest } \\
\cline { 2 - 8 } treatment & 0 & 2 & 5 & 10 & 15 & 20 & 30 \\
\hline Treated & $0.0 \mathrm{dA}$ & $0.0 \mathrm{dA}$ & $0.0 \mathrm{~dB}$ & $3.2 \mathrm{~dB}$ & $12.7 \mathrm{cB}$ & $23.3 \mathrm{bB}$ & $46.7 \mathrm{aB}$ \\
Untreated & $0.0 \mathrm{dA}$ & $0.0 \mathrm{dA}$ & $4.3 \mathrm{dA}$ & $35.0 \mathrm{cA}$ & $56.0 \mathrm{bA}$ & $59.8 \mathrm{bA}$ & $79.8 \mathrm{aA}$ \\
\hline
\end{tabular}

${ }^{(1)}$ Transformed to infection intensity index (Czermainski, 1999). ${ }^{(2)}$ Means followed by equal lowercase letters, in the rows, and capital letters, in the columns, do not differ by Tukey's test, at $5 \%$ probability. Treated, immersion of the roots in fungicide $\left(50 \mu \mathrm{g} \mathrm{mL}^{-1}\right.$ carbendazim) solution for $2 \mathrm{~min}$; untreated, roots not immersed in fungicide solution.

Table 6. Interaction effect between environmental conditions and fungicide treatment, days after harvest (DAH), and root position, on microbial deterioration ${ }^{(1)}$ in cassava roots $^{(2)}$.

\begin{tabular}{|c|c|c|c|c|c|c|c|c|c|c|c|c|}
\hline \multirow{2}{*}{$\begin{array}{l}\text { Environmental } \\
\text { condition }\end{array}$} & \multicolumn{2}{|c|}{ Fungicide treatment } & \multicolumn{7}{|c|}{ Days after harvest } & \multicolumn{3}{|c|}{ Root position } \\
\hline & Treated & Untreated & 0 & 2 & 5 & 10 & 15 & 20 & 30 & Proximal & Medial & Distal \\
\hline HTLH & $6.4 \mathrm{bB}$ & $27.3 \mathrm{aA}$ & $0.0 \mathrm{dA}$ & $0.0 \mathrm{dA}$ & $3.4 \mathrm{dA}$ & $22.5 \mathrm{cA}$ & $30.9 \mathrm{bB}$ & $33.2 \mathrm{bB}$ & $51.0 \mathrm{aB}$ & $17.1 \mathrm{aB}$ & $16.6 \mathrm{aA}$ & $15.2 \mathrm{aB}$ \\
\hline LTHH & $12.5 \mathrm{bA}$ & $26.8 \mathrm{aA}$ & $0.0 \mathrm{eA}$ & $0.0 \mathrm{eA}$ & $0.09 \mathrm{eA}$ & $15.6 \mathrm{~dB}$ & $37.1 \mathrm{cA}$ & $45.4 \mathrm{bA}$ & $64.2 \mathrm{aA}$ & $21.3 \mathrm{aA}$ & $16.9 \mathrm{bA}$ & $20.4 \mathrm{aA}$ \\
\hline
\end{tabular}

${ }^{(1)}$ Transformed to infection intensity index (Czermainski, 1999). ${ }^{(2)}$ Means followed by equal lowercase letters, in the rows, and capital letters, in the columns, do not differ by Tukey's test, at 5\% probability. HTLH, trial carried out under conditions of high temperature and low soil moisture; and LTHH, trial carried out under conditions of low temperature and high soil moisture. Treated, immersion of the roots in fungicide $\left(50 \mu \mathrm{g} \mathrm{mL}^{-1}\right.$ carbendazim) solution for $2 \mathrm{~min}$; untreated, roots not immersed in fungicide solution. 
and optimization of the procedures for germplasm screening in the search for sources of tolerance to both PPD and MD.

\section{Conclusions}

1. The genotypes have different genetic tolerances to postharvest physiological deterioration and resistance to microbial deterioration.

2. The fungicide treatment significantly reduces the severity of microbial deterioration, but has no effect on the expression of postharvest physiological deterioration in cassava roots.

3. Postharvest physiological deterioration and microbial deterioration symptoms are more pronounced under conditions of lower temperatures and higher relative humidity.

4. The storage period of up to 10 days after harvest is suitable for genotype screening, since cassava roots show lower microbial deterioration severity and high postharvest physiological deterioration expression.

5. The expression of postharvest physiological deterioration is equal in the proximal, medial, and distal parts of the root; however, since root extremities are more prone to mechanical damage, the medial part should be used for the screening.

\section{Acknowledgments}

To Fundação de Amparo à Pesquisa do Estado da Bahia (Fapesb), to Coordenação de Aperfeiçoamento de Pessoal de Nível Superior (Capes), and to Conselho Nacional de Desenvolvimento Científico e Tecnológico $(\mathrm{CNPq})$, for financial assistance and scholarship support.

\section{References}

ALVES, J.M.A.; COSTA, F.A. da; UCHÔA, S.C.P.; SANTOS, C.S.V. dos; ALBUQUERQUE, J. de A.A. de; RODRIGUES, G.S. Avaliação de dois clones de mandioca em duas épocas de colheita. Revista Agro@mbiente On-line, v.2, p.15-24, 2008.

CZERMAINSKI, A.B.C. Generalização de um índice de intensidade de infecção em experimentos de avaliação de doenças em plantas. Pesquisa Agropecuária Brasileira, v.34, p.1545-1555, 1999. DOI: 10.1590/ S0100-204X1999000900004.

EKANAYAKE, I.J.; LYASSE, O. Genotypic variations in physiological deterioration of cassava (Manihot esculenta Crantz) storage roots under inland valley conditions. Food, Agriculture and Environment, v.1, p.108-111, 2003.

HUANG, J.; BACHEM, C.; JACOBSEN, E.; VISSER, R.G.F. Molecular analysis of differentially expressed genes during postharvest deterioration in cassava (Manihot esculenta Crantz) tuberous roots. Euphytica, v.120, p.85-93, 2001. DOI: 10.1023/A:1017555605219.

IYER, S.; MATTINSON, D.S.; FELLMAN, J.K. Study of the early events leading to cassava root postharvest deterioration. Tropical Plant Biology, v.3, p.151-165, 2010. DOI: 10.1007/ s12042-010-9052-3.

LUENGO, R. de F.A.; GALBO, A.G. (Ed.). Embalagens para comercialização de hortaliças e frutas no Brasil. Brasília: Embrapa Hortaliças, 2009. 256p.

MORANTE, N.; SÁNCHEZ, T.; CEBALlOS, H.; CALlE, F.; PEREZ, J.C.; EGESI, C.; CUAMBE, C.E.; ESCOBAR, A.F.; ORTIZ, D.; CHÁVEZ, A.L.; FREGENE, M. Tolerance to postharvest physiological deterioration in cassava roots. Crop Science, v.50, p.1333-1338, 2010. DOI: 10.2135/ cropsci2009.11.0666.

OWITI, J.; GROSSMANN, J.; GEHRIG, P.; DESSIMOZ, C.; LALOI, C.; HANSEN, M.B.; GRUISSEM, W.; VANDERSCHUREN, H. iTRAQ-based analysis of changes in the cassava root proteome reveals pathways associated with post-harvest physiological deterioration. The Plant Journal, v.67, p.145-156, 2011. DOI: 10.1111/j.1365-313X.2011.0458 2.x.

REILLY, K.; BERNAL, D.; CORTÉS, D.F.; GOMEZ-VASQUEZ, R.; TOHME, J.; BEECHING, J.R. Towards identifying the full set of genes expressed during cassava post-harvest physiological deterioration. Plant Molecular Biology, v.64, p.187-203, 2007. DOI: $10.1007 / \mathrm{s} 11103-007-9144-0$.

REILLY, K.; GÓMEZ-VÁSQUEZ, R.; BUSCHMANN, H.; TOHME, J.; BEECHING, J.R. Oxidative stress responses during cassava post-harvest physiological deterioration. Plant Molecular Biology, v.53, p.669-685, 2003. DOI: 10.1023/B:PL AN.0000019076.76614.88.

SALAMI, A.O.; AKINTOKUN, A.K. Post-harvest enzymatic activities of healthy and infected Cassava (Manihot esculenta Crantz) tubers. Emirates Journal of Food and Agriculture, v.20, p.1-17, 2008. DOI: 10.9755/ejfa.v12i1.5177.

SALCEDO, A.; DEL VALLE, A.; SANCHEZ, B.; OCASIO, V.; ORTIZ, A.; MARQUEZ, P.; SIRITUNGA, D. Comparative evaluation of physiological post-harvest root deterioration of 25 cassava (Manihot esculenta) accessions: visual vs. hydroxycoumarins fluorescent accumulation analysis. African Journal of Agricultural Research, v.5, p.3138-3144, 2010.

SALCEDO, A.; SIRITUNGA, D. Insights into the physiological, biochemical and molecular basis of postharvest deterioration in cassava (Manihot esculenta) Roots. American Journal of Experimental Agriculture, v.1, p.414-431, 2011. DOI: 10.9734/ AJEA/2011/784.

SÁNCHEZ, T.; CHÁVEZ, A.L.; CEBALlOS, H.; RODRIGUES-AMAYA, D.B.; NESTEL, P.; ISHITANI, M. 
Reduction or delay of post-harvest physiological deterioration in cassava roots with higher carotenoid content. Journal of the Science of Food and Agriculture, v.86, p.634-639, 2006. DOI: 10.1002/jsfa. 2371 .

WHEATleY, C.; LOZANO, C.; GÓMEZ, G. Post-harvest deterioration of cassava roots. In: COCK, J.H.; REYES, J.A.
(Ed.). Cassava: research, production and utilization. Cali: UNDP-CIAT, 1985. p.655-671.

ZIDENGA, T.; LEVYVA-GUERRERO, E.; LUA, H.; SIRITUNGA, D.; SAYRE, R. Extending cassava root shelf life via reduction of reactive oxygen species production. Plant Physiology, v.159, p.1396-1407, 2012. DOI: 10.1104/pp.112.200345.

Received on December 15, 2014 and accepted on May 26, 2015 